\title{
A Review of Indicators of Healthy Agricultural Soils with Pea Footrot Disease Suppression Potentials
}

\author{
Ebimieowei Etebu ${ }^{1} \&$ A. Mark Osborn ${ }^{2}$ \\ ${ }^{1}$ Department of Biological Sciences, Niger Delta University, Wilberforce Island, Bayelsa State, Nigeria \\ ${ }^{2}$ Department of Biological Sciences, University of Hull, United Kingdom \\ Correspondence: Ebimieowei Etebu, Department of Biological Sciences, Niger Delta University, Wilberforce \\ Island, Bayelsa State, Nigeria. E-mail: eetebu@yahoo.com
}

Received: May 31, 2012 Accepted: June 20, 2012 Online Published: July 25, 2012

doi:10.5539/sar.v1n2p235 URL: http://dx.doi.org/10.5539/sar.v1n2p235

\begin{abstract}
The quality of a soil is often viewed in relation to its ability to suppress plant disease and enhance agricultural productivity. A soil is considered suppressive when, in spite of favourable conditions for disease incidence and development, a pathogen cannot become established, or establishes but produces no disease, or establishes and produces disease for a short time and then declines. The interplay of biotic and abiotic factors has long been known to assert disease suppressive capabilities or otherwise. However, the multi-functionality of soil makes the identification of a single property as a general indicator of soil health an uphill task. In this paper, therefore, some indicators of soil health important to agriculture are reviewed with emphasis on pea footrot disease suppression potentials. Findings show that footrot disease due to Nectria haematococca (anamorph Fusarium solani f.sp pisi) is a globally, economically important disease of peas, and an initial inoculum density of $\geq 100$ pathogenic forms of $N$. haematococca cells would produce an appreciable level of pea footrot disease depending on the relative amount of phosphorus, carbon and nitrogen present in soil. It would be desirable to confirm pea footrot disease models obtained from pot experiments with results from field experiments.
\end{abstract}

Keywords: Nectria haematococca (anamorph Fusarium solani f.sp pisi), peas, footrot disease, soil healthindicators, agriculture

\section{Introduction}

The soil is a complex and dynamic biological system, harbouring a large number of organisms that help to convert organic matter and associated nutrients from one form to another. In addition to harbouring organisms involved in the conversion and cycling of organic matter and nutrients, it also serves as an environmental filter, removing undesirable solid and gaseous constituents from air and water (Parr et al., 1992). The extent to which a soil immobilizes or chemically detoxifies toxic substances, reflects the degree of soil health in the sense that plants, humans and/or other biological components of the system are protected from harm (Singer \& Ewing, 2000).

Having a consensus definition for soil health has been difficult to arrive at, partly because of the many and varied functions of the soil in sustaining the terrestrial ecosystem (Nielsen \& Winding, 2002). Definitions of air and water quality standards have always been based on tolerable ranges of concentration of materials, beyond which they become detrimental to human health. To that extent, definition of air and water quality has widely been accepted among the rank and file of researchers for a long time, (Sojka \& Upchurch, 1999). This is not the case with soil health, variously defined in by various workers over the last decade (Nielsen \& Winding, 2002).

Historically, the quality of a soil is measured in relation to its agricultural productivity or fertility (Singer \& Ewing, 2000). However, in the 1990s, some argued that soil quality, in addition to plant productivity, also encompassed interactions with the surrounding environment, including the implications on human and animal health (Doran et al., 1994). Soil health from then was viewed as the net result of a dynamic conservation and degradation processes, which influences plant health, environmental health, food safety and quality (Halvorson et al., 1997; Parr et al., 1992).

Doran et al. (1996) defines soil health as the continued capacity of soil to function as a living system, to sustain biological productivity, promote the quality of air and water environments, and maintain plant, animal and human health. In spite of the various definitions and views by different workers, soil health has been defined, summarily, 
by all to essentially mean the capacity of soil to function as a vital living system to sustain biological productivity, promote environmental quality and maintain plant, animal and human health (Doran \& Zeiss, 2000; Halvorson et al., 1997; Karlen et al., 1997; Larson \& Pierce, 1991; Parr et al., 1992). The term "soil health" shall therefore be viewed from the standpoint of plant health in this discourse, with particular reference to pea cultivation.

Agricultural intensification is one of the major impacts on the soil environment. The advent of agriculture some 10,000 years ago has transformed the earth's landscape to yield abundance of food and fibre to meet the needs of its ever teeming human population (Doran et al., 1996). In Denmark, for example, agriculture is reported to account for two-third of the land use (OECD, 1999). Agriculture, hitherto, had relied almost solely on the internal natural resources available to it from the sun, air, rainfall, plants, animals and soil; and humans depended on natural processes and ecological associations for its productivity (Rodale, 1995). But about 100 years ago, agriculture shifted from a sole reliance on internal natural resources to external inputs such as pesticides and fertilizers, and of fossil fuels, which had been produced by green plants many millennia ago. These pose huge threats to the natural processes that sustain the global ecosphere and life on earth (Pearce \& Warford, 1993). Adverse impacts of agriculture include loss of biodiversity, nitrogen effluents into surface water, eutrophication of surface water, contamination of groundwater from pesticides and nitrate, and ammonia volatization due to over-fertilization with manure (OECD, 1999).

Deterioration of soil health is of concern not only for plants and animals but for humans also because air, groundwater and surface water consumed by humans can be adversely affected by mismanaged and contaminated soil (Oliver, 1997). As such, deteriorating soil health and the benefits of soil management have become a political concern (Nielsen \& Winding, 2002). This explains why the main thrust of the European Commission in the beginning of 2001, as contained in the draft report of the sixth Environmental Action Programme "Environment 2010: Our future, Our Choice", was the need for a systematic approach to protect soil ecosystems within Europe (European Environmental Agency, 2001). Furthermore, a proposal was made to form a European monitoring and assessment framework on soil, whose task envisaged the provision of policy-makers with relevant information on soil and the harnessing of the wealth of soil information derived from current national soil monitoring programmes (European Environmental Agency, 2001). Emphasis was placed on comparing biological properties with physical or chemical properties (European Environmental Agency, 2001).

In the eyes of an agriculturist and plant pathologist, the quality of a soil would be measured in relation to its ability to suppress plant disease and enhance agricultural productivity. A soil is considered suppressive when, in spite of favourable conditions for disease incidence and development, a pathogen cannot become established, or establishes but produces no disease, or establishes and produces disease for a short time and then declines (Cook \& Baker, 1983; Schneider, 1982). It has long been known that the physical, chemical and biological components of soil interplay to assert disease suppressiveness or conduciveness on any given soil. The interplay of these components is also responsible for the health and fertility of agricultural soils, linked to soil disease suppressiveness.

Due to the multi-functionality of soil, however, it is difficult to identify one single property as a general indicator of soil health (Doran et al., 1996). Different workers have proposed various indices and endpoints as indicators of soil health (Doran \& Parkin, 1994; Larson \& Pierce, 1994; Nielsen \& Winding, 2002; Smith et al., 2000). The respective positions notwithstanding, indicators of soil health, as it relates to plant disease suppression and/or soil fertility, could be categorised into two broad groups, viz: biotic and abiotic factors. Some of those endpoints, important to agriculture, are herein reviewed, with emphasis on pea footrot disease suppression potentials.

\section{Biotic Indicators of Soil Health}

Biotic indicators or endpoints include all aspects of association between plants and other organisms, particularly microorganisms in soils. During the last two decades, tremendous efforts have been made to study the role of microorganisms in soil processes, and their interactions with the abiotic factors of soil function (Brussard, 1998; Brussard et al., 1997; Giller, 2001; Kahindi et al., 1997; Lavelle, 1997; Lavelle et al., 1993, 1994, 2006). These studies have provided us with insight into the regulation of microbial activity, and their participation in soil's physical, chemical and biological processes, and how they influence the dynamics of decomposition and soil organic matter and plant growth (Brussard, 1998; Lavelle et al., 2006). The composition of microbial communities in soil have been studied for a long time (Girvan et al., 2003; Nannipieri et al., 2003), and are known to play key roles in the fertility/health status of soils, including agricultural soils. The beneficial roles of microorganisms in soil have been exploited in agricultural practice for decades (van Veen et al., 1997). The reasons for the intentional use of microorganisms in agricultural practice are varied. Some of these include

(i) supply of nutrients to crops 
(ii) enhancement of plant growth

(iii) improvement of soil structure

(iv) bioremediation of polluted soils through mineralization of organic pollutants

(v) bioaccumulation or microbial leaching of inorganics and

(vi.) suppression of soil-borne plant diseases (Davison, 1988; Ehrlich \& Brierley, 1990; Kennedy \& Smith, 1995; Middeldorp et al., 1990; van Elsas et al., 2002; van Veen et al., 1997).

Biotic indicators of soil quality commonly measured include soil organic matter, respiration, microbial biomass (total bacteria and fungi,) and mineralizable nitrogen (Stevenson, 1994). Although soil organic mass is generally considered to be a biological indicator, it is herein treated under chemical indicators, because plant and animals living in soil usually account for $<5 \%$ of the soil organic carbon (Stevenson, 1994). For purposes of this review, biological indicators would include plant health and productivity, pathogen density, soil microbial richness and diversity, and microbial biomass.

\section{Plant Health and Productivity}

The relationship between soil quality and plant health has long been recognised, and has occupied a position of immense economic importance, partly because of the growing dislike towards the use of chemicals, coupled with the growing global interest to maintain biological diversity. Soil disinfectants such as ethylene dibromide, and 1, 2 dibromochloropropane are now known to be environmentally hazardous and their use in agricultural soils banned (United Nations Environmental Program, 1992). The use of pesticides has also raised considerable concern among agriculturists, environmentalists and policy makers, as these substances often lead, with time, to the occurrence and build-up of resistant pests and pathogens strains (Slabaugh, 1990). This has led to an increasing demand for the development and improvement of alternative methods of sustaining agricultural productivity (Chellemi \& Porter, 2001) and assessing soil quality in relation to plant health. Soil quality and plant health are today known to be influenced by agricultural practices, such as cropping systems, inorganic/organic amendments, tilling etc (Chellemi \& Porter, 2001; Cook, 2000).

Various biological, chemical and physical parameters have been proposed to assess soil quality (Doran and Parkin, 1994; Larson and Pierce, 1994). All factors that influence soil quality are known to also influence plant health. This is because they limit optimisation and quality of yield (Cook, 2000). From the on-going, a soil could be said to be healthy only with reference to specific plant(s) or crops since different crops would require different and varying proportions of biological, chemical and physical factors for optimum productivity.

\section{Pathogen (Inoculum) Density}

This, no doubt, would be an indispensable indicator of soil health because plant disease is an outcome of the interaction between a host plant, pathogen, and environmental factors (Agrios, 1997). The inoculum load within or near fields of host plants is critical in plant disease epidemics (Cullen et al., 2001, 2002; Goud \& Termorshuizen, 2003). Generally, increasing the amount of inoculum load enhances disease severity and reduces the time required for maximal disease development (Bhatti \& Kraft, 1992; Etebu \& Osborn, 2010, 2011b; Navas-Cortés et al., 2000; Rush \& Kraft 1986; Sugha et al., 1994). Whilst the inoculum potential of a soil, defined as the pathogenic energy present to cause infection (Bouhot, 1979), is dependent on many factors, it is common practice to allow fallow periods between susceptible crops, to avoid build-up of high inoculum load in fields, and in so doing, also avoid disease outbreaks in such fields. To this effect, a 6-year rotation period is reportedly practised with pea cultivation in the Netherlands (Oyarzun et al., 1993) with a view to avoiding build-up of pea root rot pathogens. Among the fungi responsible for root rot disease complex in peas, Nectria haematococca (anamorph F. solani f.sp. pisi) is noted to be the most predominant fungus (Hwang \& Chang, 1989; Sanssené \& Didelot, 1995).

$N$. haematococca is pathogenic on all commercial processing pea cultivar (Hagedorn, 1991; Grünwald et al., 2003) and responsible for yield losses of 35-57\% (Kraft, 1984; Kraft, 2001; Oyarzun, 1993). There is currently no effective management practice capable of controlling the disease, excepting the avoidance of fields with high disease potential, as neither genetic resistance nor chemical control is effective in its management (Oyarzun, 1993).

Although $N$. haematococca has long been known as the causative agent of pea footrot disease, the use of Peptone-pentachloronitrobenzene agar (PPA) aimed at selectively isolating and quantifying $N$. haematococca in soil (Biddle pers. Comm., 2005; Oyarzun et al., 1994) has been unsuitable (Oyarzun et al., 1997), essentially because the medium is not exclusively selective for $N$. haematococca, neither does it discriminate between pathogenic and non- pathogenic forms (Etebu \& Osborn, 2009, 2010, 2011a; Funnell \& VanEtten, 2002; Kistler 
\& VanEtten, 1988; Oyarzun, 1993; Oyarzun et al., 1994). As a result, different workers called for the development of molecular quantification assays as a prerequisite for determining the soil inoculum threshold levels necessary for disease development in a host-pathogen relationship (Cullen et al., 2001, 2002). Goud and Termorshuizen (2003) attempted to quantify $N$. haematococca in soil, using molecular approaches targeting ITS regions. Unfortunately, like culture-dependent assays, molecular assays targeting the ITS region was equally unsuitable because it was also not able to discriminate between pathogenic and non-pathogenic forms (Suga et al., 2000).

The ability of Nectria haematococca to cause footrot disease in peas is linked to a cluster of six pea pathogenicity genes (PDA, PEP1, PEP2, PEP3, PEP4 and PEP5) which pathogenic strains of the fungus are known to possess (Etebu \& Osborn, 2009, 2011a; George et al., 1998; Funnell et al., 2002; George \& VanEtten, 2001; Funnell \& VanEtten, 2002; Han et al., 2001; Temporini \& VanEtten, 2002). Following the discovery of these genes, several PCR-based molecular assays have been developed to selectively detect and quantify pea pathogenic forms of $N$. haematococca in agricultural soils without recourse to culture (Etebu \& Osborn, 2009, 2010, 2011b). These assays showed that gene copy numbers of each of three genes (PDA, PEP3 and PEP5) quantified from soil-DNA were comparable to the number of pea pathogenic forms of $N$. haematococca in soil. In a related review article, Etebu and Osborn (2011d) opine that the PEP3 gene would be the most ideal indicator gene to target in the molecular quantification of pea pathogenic forms of $N$. haematococca in soil, because the PEP3 homologue is the only gene that is present exclusively in highly virulent pea pathogenic isolates (Temporini \& VanEtten, 2002; Han et al., 2001).

\section{Microbial Diversity}

The significance of biodiversity in the field of ecology has been appreciated as early as the 1950s (Hutchinson, 1959). Nielsen and Winding (2002) define Biodiversity as the variability among living organisms, including diversity within species, between species, and of ecosystems. Following the early works on biodiversity which focused on plant and animal communities, microbiologists from the 1960s began to examine the impact of biodiversity on the function and structure of microbial communities (Hariston et al., 1968; Swift, 1974). From then, the subject of microbial diversity has continuously been accorded due recognition and significance in ecological studies. For example, the 'Diversities International Research Program' was created in 1991 to promote scientific investigations into the origins and conservation of biodiversity and the impact of biodiversity on ecological functions. Also, the Biodiversity Treaty that was issued from the United Nations Conference on Environment and Development in 1992 in Rio de Janeiro, Brazil, attests to the importance of microbial diversity (Colwell, 1996).

The field of microbial biodiversity has grown significantly since the Diversities International Research Program and has resulted in a large body of scientific literature. There has been considerable development of techniques for characterizing diversity, in particular at the molecular level, for both culturable and non-culturable microorganisms (Rondon et al., 2000; Theron \& Cloete, 2000). In spite of the numerous contributions made so far in the study of microbial diversity, the general consensus is that the microbial world is much more diverse than we can appreciate at the present. Hence our understanding of the significance of biodiversity for ecological processes in the microbial world or of the ways, in which we can manipulate or manage this diversity, is largely still unknown (Bull \& Stach, 2004; Rosselló-Mora and Kämper, 2004; Tilman et al., 1997; Yachi \& Loreau, 1999). Morris et al. (2002) have largely attributed this failure or setback to problems associated with experimental designs and testing of hypothesis in ecological research. This notwithstanding, researchers have generally defined biological diversity at three levels of complexity:

(i) Genetic (intraspecies diversity),

(ii) Species (numbers of species), and

(iii) ecological (community diversity) (Harper \& Hawksworth 1995; Scholes et al., 2008).

Species richness/abundance is considered to be the fundamental measures of biodiversity (Magurran, 1988; Purvis \& Hector, 2000). Agricultural soil with diverse species of microbial community has been acknowledged to be resilient to plant disease (Peterson et al., 1998; Tilman \& Downing, 1994, Tilman et al., 1996; Walker et al., 1999).

The term 'resilience' was first introduced into ecological parlance in 1973 by C. S. Holling (1973) to elucidate the non-linear dynamics observed in ecosystems. Some define ecological resilience as the amount of disturbance that an ecosystem could withstand without altering self-organized processes and structures, whilst others view it as the time an ecosystem takes to return to a stable or equilibrium state following an ecological disturbance (Ives, 1995; Neubert \& Caswell, 1997; Tilman \& Downing, 1994). Proponents of this latter definition measure resilience by how far (in terms of time) a system has deviated from that equilibrium and how long or how quickly it returns. 
Those opposed to this school of thought are of the opinion that this return time is better described as a measure of stability rather than be viewed as a measure of resilience (Holling, 1973; Ludwig et al., 1996).

Gunderson (2000) in his excellent review describes another type of resilience whereby attention was drawn to some disturbances that could cause an irreversible shift in the structure and processes of certain ecosystems. For such, instabilities can result in a shift of the system into another stability domain different from the previous one prior to the disturbance (Holling, 1973; Ludwig et al., 1996). This concept recognises the presence of multiple stability domains and the tolerance of the system to disturbances that facilitate transitions among stable states.

The relationship between biological diversity and resilience has been described by several authors in ecological cycles (Tilman \& Downing, 1994, Tilman et al., 1996). It has been shown that biological diversity enhances the efficiency and stability of some functions of the ecosystem (Tilman \& Downing 1994; Tilman et al., 1996). The role of biodiversity in the stability of functions within an ecosystem is related to the diversity of functional groups in it, and the species diversity within the groups (Norberg et al., 2001; Walker, 1992). Walker (1992), using a very simple and illustrative analogy, categorised functional species groups in an ecosystem into two-Drivers and Passengers. According to him, "drivers" are the pillars that determine the course of an ecosystem, while the "passengers" are less important. However, as conditions change, species functional positions also change as they shift roles. Some previously playing a passenger role in Walker's analogy become drivers. Thus, according to him, ecological resilience is dependent both on the drivers, and on passengers who are potential drivers. In this way, species are said to combine to form an overlapping set of synergistic influences that help to spread risks and benefits amongst them (Peterson et al., 1998), and maintains the resilience of ecosystem structure and function (Walker et al., 1999)

Thus, in a resilient agricultural soil, one would expect a microbial community of diverse species of microorganisms with none enjoying an exclusive dominance status, in terms of abundance. Expectedly, such soils would be both resilient and suppressive to plant diseases. A recent study by Etebu and Osborn (2011c) showed that fungal richness is negatively related to pea pathogen ( $N$. haematococca) density whilst being positively correlated to pea shoot length. This confirms the widely accepted view of agricultural soils endowed with numerous fungal species to better enhance the growth and productivity of food crops.

\section{Microbial Biomass}

Soil microbial biomass represents the fraction of the soil responsible for the energy and nutrient cycling and the regulation of organic matter transformation (Gregorich et al., 1994; Turco et al., 1994). Microbial biomass has been reported to be positively correlated with decomposition rate and N-mineralization (Carter et al., 1999; Jenkinson, 1988) and grain yield in soils where organic (as opposed to conventional farming) is practised (Singh, 1995). Carter et al. (1999), recommend soil microbial biomass as indicators of soil organic carbon, because increased microbial biomass is suggestive of increased available soil nutrients.

\section{Abiotic Indicators of Soil Health}

Many studies have shown that some soils have a capacity to suppress disease incidence or severity on susceptible host plants, in spite of the presence of a pathogen and climatic conditions favourable for disease onset and development (Baker \& Cook, 1974; Schippers, 1992; Schneider, 1982; Westphal \& Becker, 2001), and such soils are adjudged healthy (Abawi \& Widmer, 2000; Mazzola, 1999; Van Bruggen \& Semenov, 2000). The ability of suppressive soils to control pathogenic activity is dependent on inherent biotic and abiotic soil properties (Alabouvette et al., 1982; Garbeva et al., 2004). Abiotic factors with such modulating influence are both chemical and physical. Some soil chemical factors that contribute to pea plant health and productivity include soil organic matter (SOM), Salinity, pH, Potassium, Phosphorus etc. Physical factors, on the other hand, would include temperature, water holding capacity (Etebu, 2008; Etebu \& Osborn, 2011c).

\section{Soil Organic Matter (SOM)}

Stevenson (1994) describes Soil Organic Matter (SOM) to mean the totality of all organic materials in soils, including litter, light fraction, microbial biomass, water-soluble organics, and stabilized organic matter (humus). Hence, according to Stevenson, SOM encompasses all plant and animals living in soil (biomass, usually accounts for $<5 \%$ of the soil organic carbon), and those that are dead, as well as their products at various stages of decomposition, up to the humic states. As a result of this elaborate description for SOM, Smith et al. (2000) assert that soil organic matter is an indispensable environmental indicator, while admitting its limitations.

The SOM potential of a soil is differentially influenced by a number of factors, such as soil texture (Smith et al., 2000). For example, whereas, temperature is inversely related to SOM (Stevenson, 1986), precipitation increases SOM in soils (Stevenson, 1994). Management practices, such as tillage, are reported to lead to loss of SOM 
(Paustian et al., 1997). SOM, however, plays very significant roles in soil. It strengthens soil aggregate, increases water retention, buffers soil $\mathrm{pH}$, chelates metals, interacts with xenobiotics, and retains cations and anions in soil systems. In so doing, SOM largely determines the physical, chemical and biological qualities of a soil (Stevenson, 1986, 1994)

Chemically, SOM includes hydrogen, carbon, oxygen, nitrogen, sulphur and phosphorus (Jenkinson, 1988). The organic carbon-to-organic nitrogen ratio $(\mathrm{C} / \mathrm{N})$, expressed as a ratio by weight, is reportedly the most studied indicator of SOM (Jenkinson, 1988). It has been found to be relatively constant for different soils under a wide range of management practices (Jenkinson, 1971). Less commonly used are concentrations of sulphur and phosphorus.

Organic carbon has been reported as a potential predictor of the ability of soils to accumulate $\mathrm{NH}_{3}$ (Tenuta \& Lazarovits, 2004), probably due to mineralization. Recent works aimed at studying various factors responsible for pea footrot disease also corroborate these earlier findings (Etebu \& Osborn, 2010, 2011c). Whilst organic carbon was observed to be positively correlated to total ammonium-nitrogen $\left(\mathrm{NH}_{4}-\mathrm{N}\right)(P \leq 0.05)$, it showed a significant $(P \leq 0.05)$ inverse correlation to pea footrot disease (Etebu \& Osborn, 2011c). Although the potential modulating role of soil organic carbon in pea footrot disease incidence and severity is not fully understood, Etebu and Osborn (2011c) opine that carbon in soil existing as sugars and carbohydrates may, depending on the relative amount of total ammonium-nitrogen, suppress the expression of the $P D A$ gene needed to initiate footrot disease in peas. Their assertion stems from the fact that the expression of the $P D A$ gene is suppressed in culture by glucose and amino acids (Khan \& Straney, 1999; Straney \& VanEtten, 1994).

\section{Salinity}

This influences decomposition of plant residues, and by extension, organic matter, indirectly and directly. It indirectly influences organic matter formation through the alteration of $\mathrm{pH}$, soil structure, texture, aeration etc (Nelson et al., 1996; Olsen et al., 1996). On the other hand, it directly dictates organic matter formation by influencing the osmotic potential of microbial activity (Singh et al., 1969).

In a relatively recent study, Etebu (2008) showed that differences in sodium concentrations between fields with prior footrot histories in the UK were not significant, and sodium was also not correlated to pea footrot disease. It, however, correlated to $\mathrm{pH}, \mathrm{C}: \mathrm{N}$ ratio and phosphate showing that salinity may indirectly influence soil health with respect to pea footrot disease.

\section{0. $\mathbf{p H}$}

Soil $\mathrm{pH}$ is one of the most important factors of soil chemical abiotic factors critical to its health. $\mathrm{pH}$ influences microbial activity and diversity (Alexander, 1980; Fierer \& Jackson, 2006). The influence on microbial activity and community would in turn significantly affect rates of decomposition of plant residues, thereby affecting organic matter content in agricultural soils, crucial to soil health (Paul \& Clark, 1989). Microbial communities and activity have been observed to change with changes in soil $\mathrm{pH}$. For example, microbial population has been observed to shift from bacteria, to actinomycetes, to fungi, as soil $\mathrm{pH}$ declines (Alexander, 1980).

Etebu (2008) showed that $\mathrm{pH}$ measured in fields with pea footrot disease history in the UK were positively correlated to pea footrot disease and inversely related to growth and yield of peas. Findings by earlier workers on the relationship between $\mathrm{pH}$ and various fungal plant diseases were inconsistent. Whilst some workers have reported a lack of relationship between $\mathrm{pH}$ and various plant diseases (Mallett \& Maynard, 1998; Pérez-Piqueres et al., 2006), others observed significant $(P \leq 0.05)$ relationships between $\mathrm{pH}$ and disease, which were either negative or positive (Höper et al., 1995; Lacey \& Wilson, 2001).

Whilst peas require a $\mathrm{pH}$ of between 5 and 8 for good growth (Unilever, 2003), the role of $\mathrm{pH}$ in soil suppressiveness (less disease) seems to depend on the host plant and pathogen involved. Oyarzun et al. (1998), while studying factors associated with soil receptivity with respect to three root rot pathogens (Thielaviopsis basicola, Aphanomyces euteiches and Fusarium solani f. sp. pisi) of peas, observed that $\mathrm{pH}$ was positively related to black root rot caused by T. Basicola, but no relationship was observed between $\mathrm{pH}$ and footrot disease caused by F. solani f. sp. pisi or soft root rot caused by A. euteiches. Soil $\mathrm{pH}$ depends on the chemical factors introduced into soil, partly due to agricultural management practice and the biotic components inherent in soil. As a result, $T$. basicola proved more pathogenic on peas in soils with a relatively high content of elements indicative of alkalinity such as total calcium and nitrate, while its pathogenicity was less severe on peas in soils with increasing carbon and high magnesium and phosphorus content (Oyarzun et al., 1998).

Rimé et al. (2003), however, observed a relationship similar to the findings of Etebu and Osborn (2011c), between $\mathrm{pH}$ and plant disease due to soil ectoparasitic nematodes. Similarly, a positive relationship between $\mathrm{pH}$ and disease 
(i.e. the more acidic the soil, the less severe the disease) was reported by Lacey and Wilson (2001) with respect to potato scab caused by Streptomyces scabies, and by Duffy et al. (1997) with respect to take-all disease of wheat caused by Gaeumannomyces graminis. However, Höper et al. (1995) observed a dissimilar (an inverse) relation between $\mathrm{pH}$ and Fusarium wilt disease (i.e. the more acidic the soil, the more severe the disease). They observed a positive correlation between $\mathrm{pH}$ and soil suppressiveness with respect to Fusarium wilt. Results from recent findings seem to suggest that acidic soils would generally lead to more suppressive soils (less disease) with respect to footrot disease due to F. solani f. sp. pisi (Etebu, 2008; Etebu \& Osborn, 2011c)

\section{Phosphate}

Apart from $\mathrm{pH}$, total phosphate concentration has also been shown to be significantly $(P \leq 0.05)$ correlated to pea footrot disease, growth, and yield (Oyarzun et al., 1998; Etebu, 2008; Etebu \& Osborn, 2011c). Like pH, it correlated positively to pea footrot disease, but inversely related to root length, shoot length, plant dry weight and pod dry weight (Etebu, 2008; Etebu \& Osborn, 2011c). Duffy et al. (1997) in their study of the take-all disease of wheat caused by Gaeumannomyces graminis, also observed a significant positive relationship between phosphorus and disease. Similarly, Oyarzun et al. (1998) also found a positive relationship between soluble phosphorus and footrot diseases in peas due to $F$. solani f. sp. pisi but not with soft rot diseases due to $A$. euteiches. The lack of a relationship between phosphorus and pea soft rot diseases due to A. euteiches, again suggests that the role of abiotic factors on soil suppressiveness or conduciveness would depend on the pathogen in question. A number of other workers also did not observe significant $(P \leq 0.05)$ relationships between phosphorus and various diseases. Some of these include Armillaria root disease of forest pines (Mallett \& Maynard, 1998); Potato scab disease of potatoes (Lacey \& Wilson, 2001), and black root rot of tobacco (Ramette et al., 2003).

Although phosphate inputs have been reported to have no effect on pea yields (McKenzie et al., 2001), the significant $(P \leq 0.05)$ positive correlation observed between phosphate and pea footrot disease on one hand, and its significant $(P \leq 0.05)$ negative correlation to pea growth and yield parameters on the other (Etebu and Osborn, 2011 c), coupled with its significant $(P \leq 0.05)$ positive correlation to two (PDA and PEP5) pea pathogenicity genes as reported by Etebu (2008), makes it a potential indicator in assessing the likelihood of pea footrot diseases in agricultural fields prior to cultivation. Additionally, phosphorus, alongside carbon and nitrogen, was identified in a pea footrot disease predictive model $[\mathrm{DI}=1.97+(3.48 *$ Phosphate $)+(-0.66 * \mathrm{C} / \mathrm{N})$, where DI $=$ Disease index] recently reported by Etebu and Osborn (2011c). A combination of these three factors was observed to account for $42 \%$ of the variability in pea footrot disease in the said predictive model (Etebu and Osborn, 2011c).

\section{Potassium}

Studies have shown that potassium is generally not a major factor in pea yields (Mckenzie et al., 2001). However, recent findings show that potassium seems to influence footrot disease (Etebu \& Osborn, 2011c) and negatively affect the growth and yield of peas (Etebu, 2008). Furthermore, although, potassium has not been shown nor reported to have a deleterious effect on peas, it has been shown to have a positive correlation with pea footrot disease pathogen density in soil. This obvious relationship makes potassium a candidate for further studies as an agricultural soil health indicator, potentially capable of influencing the outcome of pea- $N$. haematococca interaction in soil.

\section{Nitrogen}

Very few works have reported the relationship between nitrogen and pea footrot disease. However, it has been shown that nitrogen is significantly $(P \leq 0.05)$ positively correlated to pea footrot disease (Oyarzun et al., 1998, Etebu \& Osborn, 2011c). Although nitrogen was shown to be positively related to pea footrot disease, Etebu (2008) observed that it was not significantly related to pea growth and yield parameters. The effect of soil factors on plant diseases is dictated by their impact on the pathogen, the host plant, or the interaction between plant and pathogen (Alabouvette \& Steinberg, 2006). In particular, plant and microbial growth are both limited by nitrogen availability in many ecosystems (Kaye \& Hart, 1997). Although in the majority of agricultural management practices, nitrogenous fertilizers are often applied to the soil, peas are relatively unresponsive to fertilizers, particularly nitrogen, except when nodulation is poor, or fails completely (Muehlbauer et al., 1983). Peas, in association with Rhizobium, are capable of fixing atmospheric nitrogen which meets their requirement for high yield (Crozat et al., 1994). This capacity to fix nitrogen probably makes it unresponsive to fertilizer application, particularly nitrogen. As a result, excessive nitrogen in soil, not utilized by pea plants, may lead to an increase of footrot disease as observed by Etebu (2008). Total oxidised nitrogen (TON) not utilized by the plant probably enhances pea footrot disease due to any or all of the following reasons. (i.) Nitrogen, in its nitrate form, is 
indicative of alkalinity (Oyarzun et al., 1998), and as such, would lead to an increase in soil pH which has been demonstrated to show a significant positive correlation with plant disease (Etebu, 2008; Etebu \& Osborn, 2011c; Oyarzun et al., 1998; Workneh et al., 1993). (ii.) Since peas are capable of meeting their nitrogen requirements through atmospheric nitrogen fixation, excess TON not utilized by pea plants in a soil infested with pathogenic $F$. solani f. sp. pisi may become available to the pathogen and other microbes for growth and reproduction, thereby increasing the chances of inoculum proliferation in that soil. Increase in TON has been shown to reflect an increase in PEP3 gene (Etebu \& Osborn, 2011c). The PEP3 gene has been reported to be a reliable measure of pathogenic forms of Nectria haematococca (causal agent for pea footrot disease) in agricultural soils (Etebu \& Osborn, 2010). The fact that competition for nitrogen by biocontrol agents in soil suppresses growth of soil-borne plant pathogens (Scher et al., 1984), coupled with the positive relationship between TON and PEP3 gene, may further support the assumption that TON, not utilized by pea plant, may have initiated an increase in fungal pathogen numbers. Additionally, inoculating pea fields with Rhizobium species does not suppress root rot disease (Kraft, 2001) and serves no benefit to the pea plant, except in areas and fields where pea has not been planted or where residual nitrogen is low (Kraft, 2001).

Etebu (2008) has further shown that total ammonium-nitrogen $\left(\mathrm{NH}_{4}-\mathrm{N}\right)$ has no significant $(P=0.05)$ relationship with pea footrot disease, growth or yield. The form of nitrogen $\left(\mathrm{NO}_{3}\right.$ or $\left.\mathrm{NH}_{4}\right)$ has been noted as an important factor when it comes to its role in disease suppression in soil (Janvier et al., 2007). Organic carbon has been reported as a potential predictor of the ability of soils to accumulate $\mathrm{NH}_{3}$ (Tenuta \& Lazarovits, 2004), probably due to mineralization. The role of nitrogen in the conferment of soils with the capability to suppress disease seems to depend on the relative amount of carbon present in the same soil. $\mathrm{C} / \mathrm{N}$ ratio is inversely related to pea footrot disease (Etebu 2008; Etebu \& Osborn, 2011c). An increase in the amount of nitrogen in a soil with no corresponding increase in organic carbon resulted in a low $\mathrm{C} / \mathrm{N}$ ratio value, which in turn resulted in increased pea footrot disease (Etebu \& Osborn, 2011c). Various workers have shown that a high supply of nitrogen generally leads to severe disease conditions in plants (Agrios, 1997; Graham, 1983; Teng, 1994; Wild \& Jones, 1988). Oyarzun (1993) showed that foot/root rot disease reduced pea yield by over $50 \%$ even when more than $200 \mathrm{~kg} \mathrm{~N}$ per ha was applied. High amounts of nitrogen in a plant would remove carbon from metabolic pathways that lead to the synthesis of defence substances, such as phytoalexins, alkaloids and phenolics (Horsfall and Cowling, 1980). A high amount of nitrogen with no corresponding amount of carbon in soil would therefore render pea plants vulnerable to footrot disease.

\section{Water holding Capacity}

The concept of water holding capacity is defined as the amount of water a soil holds between its condition at field capacity and its permanent wilting point (Veihmeyer \& Hendrickson, 1950). Soil texture and structure, the latter playing a more visible role, are two determinants of soil moisture or water holding capacity. Water holding capacity considerably influences the growth and activity of soil microorganisms responsible for the degradation of plant residues and nutrient cycling in agricultural soils (Schomberg et al., 1994; Sommers et al., 1981; Stanford \& Epstein, 1974). Thomsen (1993) observed an increase in microbial biomass under moist soil conditions compared to wet conditions, apparently because of a limitation of oxygen under the latter condition. Pal and Broadbent (1975) observed $60 \%$ water holding capacity as being optimal for decomposition of crop residue. Decomposition is adversely affected by dry or wet soil conditions, obviously due to limitation of soil moisture or oxygen availability, both of which are needed for microbial activity (Kumar \& Goh, 2000). Etebu (2008) showed that water holding capacity was neither correlated to pea footrot disease nor inoculum density of $N$. haematococca in agricultural fields with pea footrot disease histories. It was, however, inversely correlated to carbon/nitrogen ratio which in itself was also inversely correlated to pea footrot disease.

\section{Conclusion}

The numerous conflicting reports on the relationships between soil factors and plant diseases in literature substantiate the complex nature of the interrelationship that plays out between a plant, pathogen, and the surrounding environment. They also show that the importance and role of soil physicochemical factors towards plant disease suppressiveness is yet to be fully understood.

Although works incorporating soil parameters in a predictive model for soil borne disease are scarce, a potential pea footrot disease predictive model $[\mathrm{DI}=1.97+(3.48 *$ Phosphate $)+(-0.66 * \mathrm{C} / \mathrm{N})]$ accounts for $42 \%$ of the variability of pea footrot disease. An initial inoculum density of $\geq 100$ pathogenic form of $N$. haematococca cells in soil is capable of causing an appreciable level of pea footrot disease. This, however, depends on the relative amount of phosphorus, carbon and nitrogen present in soil, amongst other factors yet to be substantiated.

The pea footrot disease predictive model identified by Etebu and Osborn (2011c) was based on findings from pot 
experiments; confirmation of these results from field experiments is therefore desirable.

\section{References}

Abawi, G. S., \& Widmer, T. L. (2000). Impact of soil health management practices on soil borne pathogens, nematodes and root diseases of vegetable crops. Appl. Soil Ecol, 15, 37-47. http://dx.doi.org/10.1016/S0929-1393(00)00070-6

Agrios, G. N. (1997). Plant pathology $4^{\text {th }}$ edition, Academic, New York.

Alabouvette, C., \& Steinberg, C. (2006). The soil as a reservoir for antagonists to plant diseases. In: An ecological and societal approach to biological control, (eds. Eilenberg J and Hokkanen HMT), Springer. pp.123-144. http://dx.doi.org/10.1007/978-1-4020-4401-4_8

Baker, K. F., \& Cook, R. J. (1974). Biocontrol of plant pathogens Freeman, Sans Francisco Bhatti, M.A. and Kraft, J.M. (1992). Effects of inoculum density and temperature on root rot and wilt of chickpea. Plant Dis., 76, 50-54.

Bouhot, D. (1979). Estimation of inoculum density and inoculum potential: techniques and their values for disease prediction. In: Soil-borne plant pathogens. (eds. Schippers, B. \& Gams, W.), Academic Press, London. pp. 250-278.

Brasier, C. M. (1991). Current questions in Phytophthora systematics: the role of the population approach. In: Phytophthora. (eds. Lucas, J. A., Shattock, R. C., Shaw, D. S., \& Cooke, L. R.), Cambridge University Press, Cambridge, United Kingdom. pp. 104-128.

Bridge, P., \& Spooner, B. (2001). Soil fungi: diversity and detection. Plant Soil, 232, 147-154. http://dx.doi.org/10.1023/A:1010346305799

Brussaard, L. (1998). Soil fauna, guilds, functional groups and ecosystem processes. Appl. Soil Ecol., 263, 1-13.

Brussaard, L., Behan-Pelletier, V. M., Bignell, D. E., Brown, V. K., Didden, W., Folgarait, P., ... Virginia, R. A. (1997). Biodiversity and ecosystem functioning in soil. AMBIO, 26, 563-570.

Bull, A. T., \& Stach, J. E. M. (2004). An overview of biodiversity-estimating the scale. In: Microbial diversity and bioprospecting (ed. Bull AT), American Society for Microbiology Press, Washington. D.C. pp. 15-28.

Carter, M. R., Grogorich, E. G., Angers, D. A., Beare, M. H., Sparling, G. P., Wardle, D. A., \& Voroney, R. P. (1999). Interpretation of microbial biomass measurements for soil quality assessment in humid temperate regions. Can. J. Soil Sci., 79, 507-520. http://dx.doi.org/10.4141/S99-012

Chellemi, D. O., \& Porter, I. J. (2001). The role of plant pathology in understanding soil health and its application to production agriculture. Austral. Pant. Pathol, 30, 130-109. http://dx.doi.org/10.1071/AP01008

Colwell, R. R. (1996). Microbial diversity and biotechnology. In: Biodiversity II: Understanding and protecting our Biological Resources, (eds. Reaka-Kudla ML, Wilson DE and Wilson EO), Joseph Henry Press, Washington. D.C. pp. 279-288.

Cook, R. J. (2000). Advances in plant health management in the twentieth century. Annu. Rev. Phytopathol, 38, 95-116. http://dx.doi.org/10.1146/annurev.phyto.38.1.95

Cook, R. J., \& Baker, K. F. (1983) The nature and practice of biological control of plant pathogens. Am. Phytopathol. Soc., St Paul Minnesota.

Crozat, Y., Aveline, A., Coste, F., Gillet, J. P., \& Domenach, A. M. (1994). Yield performance and seed production pattern of field-grown pea and soybean in relation to N nutrition. Eur. J. Agron., 3, 135-144.

Cullen, D. W., Lees, A. K., Toth, I. K., \& Duncan, J. M. (2001). Conventional PCR and real-time quantitative PCR detection of Helminthosporium solani in soil and potato tubers. Euro. J. Plant Pathol, 107, 387-398. http://dx.doi.org/10.1023/A:1011247826231

Cullen, D. W., Lees, A. K., Toth, I. K., \& Duncan, J. M. (2002). Detection of Collectotrichum coccodes from soil and potato tubers by conventional and quantitative real-time PCR. Plant Pathol, 51, 281-292. http://dx.doi.org/10.1046/j.1365-3059.2002.00690.x

Davison, J. (1988). Plant beneficial bacteria. Biotechnol, 6, 282-286. http://dx.doi.org/10.1038/nbt0388-282

Doran, J. W., \& Parkin, T. B. (1994). Defining and assessing soil quality. In: Defining soil quality for a sustainable environment (eds. Doran JW, Coleman DC, Bezdicek DF and Stewart BA), Soil Soc. America Madison, pp. 
$3-21$.

Doran, J. W., Sarrantonio, M., \& Liebig, M. A. (1996). Soil health and sustainability. In: Advances in Agronomy vol. 56 (ed. Sparks, DL). pp. 1-54.

Doran, J. W., Varvel, G. E., \& Culley, J. B. (1994). Tillage and residue management effects on soil quality and sustainable land management. In: "Proc. Interr. Workshop on Sustainable land management" Vol 2 (eds. Wood RC and Dumanski J), Agric. Inst. Canada, Ottowa, Canada. pp. 59-74.

Doran, J. W., \& Zeiss, M. R. (2000). Soil health and sustainability: managing the biotic component of soil ecology. Appl. Soil Ecol, 15, 3-11. http://dx.doi.org/10.1016/S0929-1393(00)00067-6

Ehrlich, H. L., \& Brierley, C. L. (1990). Microbial Mineral Recovery, McGraw-Hill Publishing Co., New York.

Etebu, E. (2008). Molecular detection and quantification of the pea footrot disease pathogen (Nectria haematococca) in agricultural soils: A potential model for disease prediction. Ph.D. Thesis, The University of Sheffield, Sheffield, UK.

Etebu, E., \& Osborn, A. M. (2009). Molecular assays reveal the presence and diversity of genes encoding pea footrot pathogenicity determinants in Nectria haematococca and in agricultural soils. J. Appl. Microbiol., 106(5), 1629-1639. http://dx.doi.org/10.1111/j.1365-2672.2008.04130.x

Etebu, E., \& Osborn, A. M. (2010). Molecular quantification of the pea footrot disease pathogen (Nectria haematococca) in agricultural soils. $\quad$ Phytoparasit, $38, \quad$ 447-454. http://dx.doi.org/10.1007/s12600-010-0122-8

Etebu, E., \& Osborn, A. M. (2011a). Pea footrot disease depends on the combination of Pathogenicity genes in Nectria haematococca. Asian J. Agric. Sci, 3(3), 156-161.

Etebu, E., \& Osborn, A. M. (2011b). Molecular prediction of pea footrot disease in agricultural soils. Asian J. Agric. Sci., 3(6), 417-426.

Etebu, E., \& Osborn, A. M. (2011c). A potential model for pea footrot disease prediction. Asian J. Agric. Sci, 3 (3), 177-186.

Etebu, E., \& Osborn, A. M. (2011d). In Search of target gene(s) to quantify pea pathogenic Nectria haematococca in Agricultural Soils. Curr. Res. J. Biol. Sci, 3(3), 195-208.

European Environmental Agency. (2001). Proposal for a european soil monitoring and assessment framework, Technical Report no. 61, European Environmental Agency, Copenhagen, Denmark.

Fierer, N., \& Jackson, R. B. (2006). The diversity and biogeography of soil bacterial communities. Proc. Natl. Acad. Sci, 103, 626-631. http://dx.doi.org/10.1073/pnas.0507535103

Funnell, D. L., Matthews, P. S., \& VanEtten, H. D. (2002). Identification of new pisatin demethylase genes (PDA5 and $P D A 7)$ in Nectria haematococca and non-mendelian segregation of pisatin demethylating ability and virulence on pea due to loss of chromosomal elements. Fungal Genet. Biol, 37, 121-133. http://dx.doi.org/10.1016/S1087-1845(02)00503-0

Funnell, D. L., \& VanEtten, H. D. (2002). Pisatin demethylase genes are on dispensable chromosomes while genes for pathogenicity on carrot and ripe tomato are on other chromosomes in Nectria haematococca, Mol. Plant Microbe Interact, 15, 840-846. http://dx.doi.org/10.1016/S1087-1845(02)00503-0

Garbeva, P., van Veen, J. A., \& van Elsas, J. D. (2004). Microbial diversity in soil: Selection of microbial populations by plant and soil type and implications for disease suppressiveness. Annu. Rev. Phytoplathol, 42, 243-270. http://dx.doi.org/10.1146/annurev.phyto.42.012604.135455

George, H. L., Hirschi, K. D., \& VanEtten, H. D. (1998). Biochemical properties of the products of cytochrome P450 genes (PDA) encoding pisatin demethylase activity in Nectria haematococca. Arch. Microbiol, 170, 147-154. http://dx.doi.org/10.1007/s002030050627

George, H. L., \& VanEtten, H. D. (2001). Characterization of pisatin-inducible cytochrome P450s in fungal pathogens of pea that detoxify the pea phytoalexin pisatin. Fungal Genet. Biol, 33, 37-48. http://dx.doi.org/10.1006/fgbi.2001.1270

Giller, K. E. (2001). Nitrogen fixation in tropical cropping systems, $2^{\text {nd }}$ edition, CAB International, Wallingford, Oxon, United Kingdom. http://dx.doi.org/10.1079/9780851994178.0000

Girvan, M. S., Bullimore, J., Pretty, J. N., Osborn, A. M., \& Ball, A. S. (2003) Soil type is the primary determinant of the composition of the total and active bacterial communities in arable soils. Appl. Environ. Microbiol, 69, 
1800-1809. http://dx.doi.org/10.1128/AEM.69.3.1800-1809.2003

Goud, J. C., \& Termorshuizen, A. J. (2003). Quality of methods to quantify microsclerotia of Verticillium dahliae in soil. Eur. J. Plant Pathol, 109, 523-534. http://dx.doi.org/10.1023/A:1024745006876

Graham, R. D. (1983). Effects of nutrient stress on susceptibility of plants with particular reference to the trace elements. Adv. Bot. Res, 10, 221-276. http://dx.doi.org/10.1016/S0065-2296(08)60261-X

Gregorich, E. G., Carter, M. R., Angers, D. A., Monreall, C. M., \& Ellert, B. H. (1994). Towards a minimum data set to assess soil organic-matter quality in agricultural soils. Can. J. Soil Sci, 74, 367-385. http://dx.doi.org/10.4141/cjss94-051

Grünwald, N. J., Coffman, V. A., \& Kraft, J. M. (2003). Sources of partial resistance to Fusarium root rot in the Pisum core collection. Plant Dis., 87, 1197-2001. http://dx.doi.org/10.1094/PDIS.2003.87.10.1197

Hagedorn, D. J. (1991). Handbook of pea diseases, Cooperative Extension Publications, University of Wisconsin, Madison, USA.

Halvorson, J. J., Smith, J. L., \& Papendick, R. I. (1997). Issues of scale for evaluating soil quality. J. Soil Water Conserv., 52, 26-30.

Han, Y. N., Liu, X. G., Benny, U., Kistler, H. C., \& VanEtten, H. D. (2001). Genes determining pathogenicity to pea are clustered on a supernumerary chromosome in the fungal plant pathogen Nectria haematococca. Plant J., 25, 305-314. http://dx.doi.org/10.1046/j.1365-313x.2001.00969.x

Hariston, N. G., Allan, J. D., Colwell, R. K., Futuyma, D. J., Howell, J., Lubin, M. D., Mathias, J., \& Vandermeer, J. H. (1968). The relationship between species diversity and stability: an experimental approach with protozoa and bacteria. Ecol., 49, 1091-1101. http://dx.doi.org/10.2307/1934492

Harper, J. L., \& Hawksworth, D. L. (1995). Preface. In: Biodiversity, measurement and estimation (ed. Hawksworth DL), Chapman \& Hall, London, UK. pp. 5-12.

Hollings, C. S. (1973). Resilience and stability of ecological systems. Annu. Rev. Ecol. Syst., 4, 1-23. http://dx.doi.org/10.1146/annurev.es.04.110173.000245

Höper, H., \& Alabouvette, C. (1996). Importance of physical and chemical soil properties in the suppressiveness of soils to plant diseases. Eur. J. Soil Biol., 32, 41-58.

Höper, H., Steinberg, C., \& Alabouvette, C. (1995). Involvement of clay type and pH in the mechanism of soil suppressiveness to Fusarium wilt of flax. Soil Biol. Biochem., 27, 955-967. http://dx.doi.org/10.1016/0038-0717(94)00238-V

Horsfall, J. G., \& Cowling, E. B. (1980). How plant defend themselves, Acad. Press, New York.

Hutchinson, G. E. (1959) Homage to santa rosalia, or why are there so many kinds of animals? Am. Nat, 93, 145-159. http://dx.doi.org/10.1086/282070

Hwang, S. F., \& Chang, K. F. (1989). Incidence and severity of root rot disease complex of field peas in northeastern Alberta in 1988. Can. Plant Dis. Surv., 69, 139-141.

Ives, A. R. (1995). Measuring resilience in stachastic-system. Ecol. Monog, 65, 217-233. http://dx.doi.org/10.2307/2937138

Janvier, C., Villeneuve, F., Alabouvette, C., Edel-Hermann, V., Mateille, T., \& Steinberg, C. (2007). Soil health through soil disease suppression: which strategy from descriptors to indicators. Soil Biol. and Biochem., 39, 1-23. http://dx.doi.org/10.1016/j.soilbio.2006.07.001

Jenkinson, D. S. (1971). The accumulation of organic matter in soil left uncultivated. Rothamsted Experimental Station Report for 1970, Part 2, Lawes Agricultural Trust, Harpenden, UK. pp. 113-137.

Jenkinson, D. S. (1988). Soil organic matter. In: Russell's Soil Conditions and Plant Growth, $11^{\text {th }}$ edition, (ed. Alan Wild), Longman Group UK. pp. 564-607.

Kahindi, J. H. P., Woomer, P., George, T., Moreira, F. M. D., Karanja, N. K., \& Giller, K. E. (1997). Agricultural intensification, soil biodiversity and ecosystem function in the tropics: The role of nitrogen-fixing bacteria. Appl. Soil Ecol., 6, 55-76. http://dx.doi.org/10.1016/S0929-1393(96)00151-5

Kaye, J. P., \& Hart, S. C. (1997). Competition for nitrogen between plants and soil microorganisms. Trends Ecol. Evol., 12, 139-143. http://dx.doi.org/10.1016/S0169-5347(97)01001-X

Kennedy, A. C., \& Smith, K. L. (1995). Soil microbial diversity and the sustainability of agricultural soils. Plant 
Soil, 170, 75-86. http://dx.doi.org/10.1007/BF02183056

Khan, R., \& Straney, D. C. (1999). Regulatory signals influencing expression of the PDA1 gene of Nectria haematococca MPVI in culture and during pathogenesis of pea. Mol. Plant-Microbe Interact, 12, 733-742. http://dx.doi.org/10.1094/MPMI.1999.12.8.733

Kistler, H. C., \& VanEtten, H. D. (1988). Nectria haematococca. In: Genetics of plant Pathogenic Fungi, (ed. Sidhu GS) Academic Press, New York. Pp. 189-206.

Kraft, J. M. (1984). Fusarium root rot. In: Compendium of pea diseases (ed. Hagedorn DJ), Am. Phytopathol. Soc. pp. 30-31.

Kraft, J. M. (2001). Fusarium root rot. In: Compendium of pea diseases, (eds. Kraft JM and Pfleger FL), the Am. Phytopathol. Soc., St. Paul, MN, USA. pp. 13-14.

Kuan, T. L., \& Erwin, D. C. (1980). Formae speciales differentiation of Phytophthora magasperma isolates from soybean and alfalfa. Phytopathol., 70, 333-338. http://dx.doi.org/10.1094/Phyto-70-333

Kumar, K., \& Goh, K. M. (2000). Crop residues and management practices: effects on soil quality, soil nitrogen dynamics, crop yield and nitrogen recovery. In: Advances in Agronomy vol. 68 (ed. Sparks DL) pp. 197-319.

Larson, W. E., \& Pierce, F. J. (1994). The dynamics of soil quality as a measure of sustainable management. In: Defining soil quality for a sustainable environment (eds. Doran JW, Coleman DC, Bezdicek DF and Stewart BA), Spec. Publ. No. 35, Soil Sci. Soc. Am. Soc. Agron. Madison, WI. pp. 37-51.

Lavelle, P., Blanchart, E., Martin, S., Barois, S., Toutain, F., Spain, A., \& Schaefer, R. (1993). A hierarchical model for decomposition in terrestrial ecosystem application to soils in the humid tropics. Biotropica, 25, 130-150. http://dx.doi.org/10.2307/2389178

Lavelle, P., Dangerfield, M., Fragosa, C., Eschenbrenner, V., Lopez-Hernandez, D., Pashanasi, B., \& Brussard, L. (1994). The relationship between soil macrofauna and tropical soil fertility. In: The Biological Management of Tropical Soil Fertility. (eds. Woomer PL \& Swift MJ), A Wiley/Sayce Publication. pp. 137-169.

Lavella, P., Decaëns, T., Aubert, M., Barot, S., Blouin, M., Bureau, F., Margerie, P., Mora, P., \& Rossi, J. P. (2006). Soil invertebrates and ecosystem services. Eur. J. Soil Biol., 42, 3-15. http://dx.doi.org/10.1016/j.ejsobi.2006.10.002

Lévesque, C. A. (1997). Molecular detection tools in integrated disease management: overcoming current limitations. Phytoparasitica, 25, 3-6. http://dx.doi.org/10.1007/BF02981473

Ludwig, D., Walker, B., \& Holling, C. S. (1996). Sustainability, stability and resilience. Conserv. Ecol., 1, 1-27.

Magurran, A. E. (1988) Ecological diversity and its measurement, Princeton University Press, USA.

Mahuku, G. S., \& Platt, H. W. (2002). Quantifying Verticillium dahliae in soils collected from potato fields using a competitive PCR aasay. Am. J. Pot. Res., 79, 107-117. http://dx.doi.org/10.1007/BF02881519

Mallett, K. I., \& Maynard, D. G. (1998). Armillaria root disease, stand characteristics, and soil properties in young lodgepole pine. Forest Ecol. Manag, 105, 37-44. http://dx.doi.org/10.1016/S0378-1127(97)00294-6

Mazzola, M. (1999). Transformation of soil microbial community structure and Rhizoctonia-suppressive potential in response to apple roots. Phytopathol., 89, 920-927. http://dx.doi.org/10.1094/PHYTO.1999.89.10.920

McKenzie, R. H., Middleton, A. B., Solberg, E. D., DeMulder, J., Flore, N., Clayton, G. W., \& Bremer, E. (2001). Response of pea to rate and placement of phosphate fertilizer in Alberta. Can. J. Plant Sci, 81, 645-649. http://dx.doi.org/10.4141/P01-007

Middeldorp, P. J. M., Briglia, M., \& Salkinoja-Salonen, M. S. (1990). Biodegradation of pentachlorophenol in natural polluted soil by inoculated Rhodococcus chlorophenolica. Microb. Ecol, 20, 123-139. http://dx.doi.org/10.1007/BF02543872

Morris, C. E., Bardin, M., Berge, O., Frey-Klett, P., Fromin, N., Girardin, H., ... Troussellier, M. (2002). Microbial biodiversity: approaches to experimental design and hypothesis testing in primary scientific literature from 1975 to 1999. Microbiol. Mol. Biol. Rev, 66, 592-616. http://dx.doi.org/10.1128/MMBR.66.4.592-616.2002

Muehlbauer, F. J., Short, R. W., \& Kraft, J. M. (1983). Description and culture of dry peas, USAD-ARS Agricultural Reviews and Manuals, Western Series, No. 37. Western Region, Oakland, California.

Nannipieri, P., Ascher, J., Ceccherini, M. T., Landi, L., Pietramellara, G., \& Renella, G. (2003). Microbial diversity 
and soil functions. Eur. J. Soil Sci, 54, 655-670. http://dx.doi.org/10.1046/j.1351-0754.2003.0556.x

Navas-Cortés, J. A., Alcalá-Jiménez, A. R., Hau, B., \& Jiménez-Díaz, R. M. (2000). Influence of inoculum density of races 0 and 5 of Fusarium oxysporum f. sp. ciceris on development of Fusarium wilt in chickpea cultivars. Eur. J. Plant Pathol, 106, 135-146. http://dx.doi.org/10.1023/A:1008727815927

Neubert, M. G., \& Caswell, H. (1997). Alternatives to resilience for measuring the responses of ecological-systems $\begin{array}{llll}\text { to } & \text { Ecol, } & \text { 2347-2360. }\end{array}$ http://dx.doi.org/10.1890/0012-9658(1997)078[0653:ATRFMT]2.0.CO;2

Nielsen, M. N., \& Winding, A. (2002). Microorganisms as indicators of soil health, Ministry of Environment, National Environmental Research Institute, Denmark, Technical Report No. 388.

Norberg, J., Swaney, D. P., \& Dushoff, J. (2001). Phenotypic diversity and ecosystem functioning in changing environments: a theoretical framework, Proc. Natl. Acad. Sci USA, 98, 11376-11381. http://dx.doi.org/10.1073/pnas.171315998

Oliver, M. A. (1997). Soil and human health: a review. Euro. J. Soil Sci, 48, 573-592. http://dx.doi.org/10.1111/j.1365-2389.1997.tb00558.x

Olsen, M. W., Frye, R. J., \& Glenn, E. P. (1996). Effect of salinity and plant species on CO2 flux and leaching of dissolved organic carbon during decomposition of plant residues. Plant Soil, 179, 183-188. http://dx.doi.org/10.1007/BF00009327

Organisation for Economic Co-operation and Development. (1999). Environmental performances reviews, Denmark. OECD Publications, Paris.

Otten, W., Filipe, J. A. N., \& Gilligan, C. A. (2004). An empirical method to estimate the effect of soil on the rate for transmission of damping-off disease. New Phytol, 162, 231-238. http://dx.doi.org/10.1111/j.1469-8137.2004.01011.x

Oyarzun, P. J. (1993). Bioassay to assess root rot in pea and effect of root rot on yield. Neth. J. Plant Pathol, 99, 61-75. http://dx.doi.org/10.1007/BF01998474

Oyarzun, P. J., Dijst, G., \& Maas, P. W. Th. (1994). Determination and analysis of soil receptivity to Fusarium solani f. sp. pisi causing dry root rot of peas. Phytopathol, 82, 834-842. http://dx.doi.org/10.1094/Phyto-84-834

Oyarzun, P. J., Dijst, G., Maas, P. W. Th., \& Gerlagh, M. (1995). Soil receptivity to root rot of grain legumes. Grain legumes. pp. 16-17.

Oyarzun, P. J., Dijst, G., Zoon, F. C., \& Maas, P. W. Th. (1997). Comparison of soil receptivity to Thielaviopsis basicola, Aphanomyces euteiches, and Fusarium solani f. sp. pisi causing root rot in pea. Phytopathol, 87, 534-541. http://dx.doi.org/10.1094/PHYTO.1997.87.5.534

Oyarzun, P., Gerlagh, M., \& Hoogland, A. E. (1993). Relation between cropping frequency of peas and other legumes and foot and root rot in peas. Neth. J. Plant Pathol, 99, 35-44. http://dx.doi.org/10.1007/BF01974783

Oyarzun, P., Gerlagh, M., \& Zadoks, J. C. (1998). Factors associated with soil receptivity to some fungal root rot pathogens of peas. Appl. Soil Ecol, 10, 151-169. http://dx.doi.org/10.1016/S0929-1393(98)00042-0

Pal, D., \& Broadbent, F. E. (1975). Influence of moisture on rice straw decomposition in soils. Soil Sci. Am. Proc, 39, 59-63. http://dx.doi.org/10.2136/sssaj1975.03615995003900010018x

Parr, J. F., Papendick, R. I., Hornick, S. B., \& Meyer, R. E. (1992). Soil quality: attributes and relationship to alternative and sustainable agriculture. Am. J. Altern. Agric, 7, 5-11. http://dx.doi.org/10.1017/S0889189300004367

Paul, E. A., \& Clark, F. E. (1989). Soil microbiology and biochemistry, Academic Press, Orlando, FL.

Paustian, K., Collins, H. P., \& Paul, E. A. (1997). Management controls on soil carbon. In: Soil organic matter in temperate agroecosystems (eds. Paul EA, Elliot ET, Paustian K and Cole CV), CRC Press, Boca Raton, FL. pp. 15-49.

Pearce, D., \& Warford, J. (1993). World without end, World Bank, Washington DC.

Pérez-Piqueres, A., Edel-Hermann, V., Alabouvette, C., \& Steinberg, C. (2006). Response of soil microbial communities to compost amendments. Soil Biol. Biochem, 38, 460-470. http://dx.doi.org/10.1016/j.soilbio.2005.05.025 
Peterson, G., Allen, C., \& Holling, C. S. (1998). Ecological resilience, biodiversity, and scale. Ecosyst, 1, 6-18. http://dx.doi.org/10.1007/s100219900002

Purvis, A., \& Hector, A. (2000). Getting the measure of biodiversity. Nature, 405, 212-219. http://dx.doi.org/10.1038/35012221

Ramette, A., Moënne-Loccoz, Y., \& Defago, G. (2003). Prevalence of fluorescent Pseudomonas producing antifungal phloroglucinols and/or hydrogen cyanide in soils naturally suppressive or conducive to tobacco black root rot. Fems Microbiol. Ecol, 44, 35-43. http://dx.doi.org/10.1111/j.1574-6941.2003.tb01088.x

Rodale, R. (1995). Alternative Agriculture. J. Soil Water Conserv, 39, 294-296.

Rondon, M. R., August, P. R., Betterman, A. D., Brady, S. F., Grossman, T. H., Liles, M. R., ... Goodman, R. M. (2000). Cloning and Soil metagenome: a strategy for assessing the genetic and functional diversity of uncultured microorganisms. Appl. Environ. Microbiol, 66, 2541-2547. http://dx.doi.org/10.1128/AEM.66.6.2541-2547.2000

Rosselló-Mora, R., \& Kämper, P. (2004). Defining microbial diversity-the species concept for prokaryotic and eukaryotic microorganisms. In: Microbial diversity and bioprospecting (ed. Bull AT), American Society for Microbiology Press, Washington, D.C. pp. 29-39.

Rush, C. M., \& Kraft, J. M. (1986). Effects of inoculum density and placement on Fusarium root rot of peas. Phytopathol, 76, 1325-1329. http://dx.doi.org/10.1094/Phyto-76-1325

Sanssené, J., \& Didelot, D. (1995). Root necrosis in peas: insidious diseases, Grain legumes, 9, 14-15.

Scher, F. M., Ziegle, J. S., \& Kloepper, J. W. (1984). A method for assessing the root colonization capacity of bacteria on maize. Can. J. Microbiol, 30, 151-157. http://dx.doi.org/10.1139/m84-024

Schippers, B. (1992). Prospects for management of natural suppressiveness to control soilborne pathogens. In: Biological control of plant diseases, progress and challenges for the future, (eds. Tjamos EC, Papavizas GC and Cook RJ) NATO ASI, Life Sciences 230. Plenum Press, New York. pp. 21-34.

Schneider, R. W. (ed.). (1982). Suppressive soils and plant disease. The Am. Phytopathol. Soc. St Paul MN USA.

Scholes, R. J., Mace, G. M., Turner, W., Geller, G. N., Jürgens, N., Larigauderie, A., ... Mooney, H. A. (2008) Toward a global biodiversity observing system. Sci, 321, 1044-1045. http://dx.doi.org/10.1126/science.1162055

Schomberg, H. H., Steiner, J. L., \& Unger, P. W. (1994). Decomposition and nitrogen dynamics of crop residues: residue quality and water effects. Soil Sci Soc. Am J, 58, 372-381. http://dx.doi.org/10.2136/sssaj1994.03615995005800020019x

Singer, M. J., \& Ewing, S. (2000). Soil quality. In: Handbook of soil science (ed. Sumner ME), CRC Press, Boca Raton. pp. 271-298.

Singh, B. R., Agarwal, A. S., \& Kanehiro, Y. (1969). Effects of chloride salts on ammonium nitrogen release in two Hawaiian soils. Soil Sci. Soc. Am. Proc, 33, 557-568. http://dx.doi.org/10.2136/sssaj1969.03615995003300040021x

Slabaugh, W. R. (1990). New approaches for chlorothalonil use in strategies to control M. fijiensis. In: Sigatoka leaf spot diseases of bananas (eds. Fullerton RA and Stover RH), Proc. International Workshop held at San José, Costa Rica (1989), INIBAP, Montpellier, France. pp. 159-166.

Smith, O. H., Petersen, G. W., \& Needelman, B. A. (2000). Environmental indicators of agroecosystems. In: Advances in Agronomy vol. 69 (ed. Sparks DL) pp. 75-97.

Sojka, R. E., \& Upchurch, D. R. (1999). Reservations regarding the soil quality concept. Soil Sci. Soc. Am. J, 63, 1039-1054. http://dx.doi.org/10.2136/sssaj1999.6351039x

Sommers, L. E., Gilmour, C. M., Wildung, R. E., \& Beck, S. M. (1981). The effect of water potential on decomposition processes in soils. In: Water potential relations in soil microbiology (eds. Parr JF, Gardner WR and Elliot LF) Spec. Publ. No. 9, Soil Sci. Soc. Am., Madison, WI. pp. 97-117.

Stacey, A. J., Truscott, J. E., Asher, M. J. C., \& Gilligan, C. A. (2004). A model for the invasion and spread of rhizomania in the United Kingdom: implications for disease control strategies. Phytopathol, 94, 209-215. http://dx.doi.org/10.1094/PHYTO.2004.94.2.209

Stanford, G., \& Epstein, E. (1974). Nitrogen mineralisation-water relations in soil. Soil Sci. Soc. Am. Proc, 38,103-106. http://dx.doi.org/10.2136/sssaj1974.03615995003800010032x 
Stevenson, F. J. (1986). Cycles of soil: Carbon, nitrogen, phosphorus, sulfur, micronutrients, Wiley, New York.

Stevenson, F. J. (1994). Humus chemistry: genesis, composition, reactions, Wiley, New York.

Straney, D. C., \& VanEtten, H. D. (1994). Characterization of the PDA1 promoter of Nectria haematococca and identification of a region that binds a pisatin-responsive DNA binding factor. Mol. Plant-Microbe Interact, 7 , 713-725. http://dx.doi.org/10.1094/MPMI-7-0256

Suga, H., Hasegawa, T., Mitsui, H., Kageyama, K., \& Hyakumachi, M. (2000). Phylogenetic analysis of the phytopathogenic fungus Fusarium solani based on the rDNA-ITS region. Mycol. Res, 104, 1175-1183. http://dx.doi.org/10.1017/S0953756200002719

Sugha, S. K., Kapoor, S. K., \& Singh, B. M. (1994). Factors influencing Fusarium wilt of chickpea (Cicer arietinum L.), Indian J. Mycol. Pl. Pathol, 24, 97-102.

Temporini, E. D., \& VanEtten, H. D. (2002). Distribution of the pea pathogenicity (PEP) genes in the fungus Nectria haematococca mating population VI. Curr. Genet, 41, 107-114. http://dx.doi.org/10.1007/s00294-002-0279-x

Teng, P. S. (1994). The epidemiological basis for blast management. In: Rice blast disease (eds. Zeigler RS, Leone SA and Teng PS), Wallingford, UK: CABI and IRRI, pp. 409-433.

Tenuta, M, \& Lazarovits, G. (2004). Soil properties associated with the variable effectiveness of meat and bone meal to kill microsclerotia of Verticillium dahliae. Appl. Soil Ecol, 25, 219-236. http://dx.doi.org/10.1016/j.apsoil.2003.09.007

Theron, J., \& Cloete, T. E. (2000). Molecular techniques for determining microbial diversity and community structure in natural environments. Crit. Rev. Microbiol, 26, 37-57. http://dx.doi.org/10.1080/10408410091154174

Thomsen, I. K. (1993). Turnover of ${ }^{15} \mathrm{~N}$-straw and $\mathrm{NH}_{4} \mathrm{NO}_{3}$ in a sandy loam soil: effect of previous straw disposal

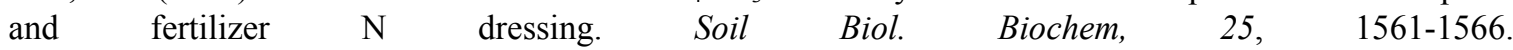
http://dx.doi.org/10.1016/0038-0717(93)90011-Y

Tilman, D., \& Downing, J. A. (1994). Biodiversity and stability in grasslands. Nature, 367, 363-365. http://dx.doi.org/10.1038/367363a0

Tilman, D., Knops, J., Wedin, D., Reich, P., Ritchie, M., \& Siemann, E. (1997). The influence of functional diversity and composition on ecosystem processes. Science, 277, 1300-1302. http://dx.doi.org/10.1126/science.277.5330.1300

Tilman, D., Wedin, D., \& Knops, J. (1996). Productivity and sustainability influenced by biodiversity in grassland ecosystems. Nature, 379, 718-720. http://dx.doi.org/10.1038/379718a0

Turco, R. F., Kennedy, A. C., \& Jawson, M. D. (1994). Microbial indicators of soil quality. In: Defining soil quality for a sustainable environment (eds. Doran JW, Coleman DC, Bezdicek DF and Stewart BA), Soil Soc. Am. Madison. pp. 73-90.

Unilever. (2003). Sustenable vining peas: Good agricultural practice guide.

United Nations Environmental program. (1992). Montreal Protocol Assessment Supplement, Methyl Bromide: Its Science, Technology and Economics. Synthesis Report of the Methyl Bromide Interim Scientific Assessment and Methyl Bromide Interim Technology and Economic Assessment.

van Bruggen, A. H. C., \& Semenov, A. M. (2000). In Search of biological indicators for soil health and disease suppression. Appl. Soil Ecol, 15, 13-24. http://dx.doi.org/10.1016/S0929-1393(00)00068-8

van Elsas, J D., Garbeva, P., \& Salles, J. (2002). Effects of agronomical measures on the microbial diversity of soils as related to the suppression of soil-borne plant pathogens. Biodegradation, 13, 29-40. http://dx.doi.org/10.1023/A:1016393915414

van Veen, J. A., van Overbeek, L. S., \& van Elsas, J. D. (1997) Fate and activity of microorganisms introduced into soil. Microbiol. Mol. Biol. Rev, 61, 121-135.

Veihmeyer, R. T., \& Hendrickson, A. H. (1950). Soil moisture in relation to plant growth. Annu. Rev. Plant Physiol, 1, 285-304. http://dx.doi.org/10.1146/annurev.pp.01.060150.001441

Walker, B. H. (1992). Biological diversity and ecological redundancy. Conserv. Biol, 6, 18-23. http://dx.doi.org/10.1046/j.1523-1739.1992.610018.x 
Walker, B., Kinzig, A., \& Langridge, J. (1999). Plant attribute diversity, resilience and ecosystem function: The nature and significance of dominant and minor species. Ecosyst, 2, 95-113. http://dx.doi.org/10.1007/s100219900062

Westphal, A., \& Becker, J. O. (2001). Soil suppressiveness to Heterodera schachtii under different cropping sequences. Nematol, 3, 551-558. http://dx.doi.org/10.1163/156854101753389167

Wild, A., \& Jones, L. H. P. (1998). Mineral nutrition of crop plants. In: Russell's Soil Conditions and Plant Growth, $11^{\text {th }}$ Edition, (ed. Alan Wild), Longman Group UK Ltd. pp. 69-112.

Yachi, S., \& Loreau, M. (1999). Biodiversity and ecosystem productivity in a fluctuating environment: The insurance hypothesis. Proc. Natl. Acad. Sci. USA, 96, 1463-1468. http://dx.doi.org/10.1073/pnas.96.4.1463 